\title{
Literary Motives of Sufizm and Spiritual, Moral Ideas in the Lyrics of Jamal Kamal
}

\author{
Nazarova Dildora
}

\begin{abstract}
In all religions of the world there is a place for spiritual and moral improvement of a man. In the Islamic religion, special importance is attached to the spiritual formation of the individual. The article reveals the essence of the spiritual and moral potential of religion on the example of the work of the Uzbek poet and translator Jamal Kamal. To show the role of advanced Islamic ideas, as one of the means for the comprehensive formation of the spiritual and aesthetic appearance of modern man, the poet turned to Sufism literature. His work can be a striking example of this phenomenon in Uzbek literature, since his work is an expression of his multifaceted, unique talent. It is well known that in all religions of the world, particular attention is paid to morals and moral maturity. However, the concept of good morals in Islam has risen to a higher level. In this article, it is written that Jamal Kamal is a poet who has built the immortal ideas of Oriental philosophy capable of raising the soul and spirit of humanity, that is, healing, to the status of the Truth and Verity.
\end{abstract}

Keywords : Sufism, soul, spirit, soil, truth, God, Lord, essence.

\section{INTRODUCTION}

T owards the end of the 20th century, the Uzbek national lyrics significantly increased interest in the motives of Tasawwuf literature (Sufism). Of course, the writers of this period turned to the advanced ideas of the philosophy of Islam, to the sources, based on the needs and desires of today. To show the role of advanced Islamic ideas, as one of the means for the comprehensive formation of the spiritual and aesthetic appearance of modern man, poets turned to a number of topics in Sufism literature.

\section{LITERATURE REVIEW}

Jamal Kamal worked fruitfully as a poet, and is recognized as a national poet of Uzbekistan. His works "The World Looks Into My Soul” (“Olam kirar yuragimga" 1968), "The beam shines on the peaks" (“ўққilarga ғғildi ғғdu” 1971), "Stone Excitement" ("Tosh tuғyong" 1973), "The Solar Spring" ( "Kuyosh Chashmashi" 1975), "Reflections" ("Tafakkur" 1979), “Сup" ("Қадах" 1980), "Suvaido" (1983), and "Best Favorites" included the best poems written in rhymes of Uzbek classical literature barmok and aruz. In 2012, the poetry collection "Travel Notebook" was published.

Revised Manuscript Received on October 15, 2019.

* Correspondence Author

Nazarova Dildora*, Assistant of the Department of Pedagogy, Psychology and Languages, Bukhara State Medical Institute.

\section{MATH}

If you are using Word, use either the Microsoft Equation Editor or the MathType add-on (http://www.mathtype.com) for equations in your paper (Insert $\mid$ Object $\mid$ Create New | Microsoft Equation or MathType Equation). "Float over text" should not be selected.

\section{RESEARCH METHODOLOGY}

Jamal Kamal's work can be a striking example of this phenomenon in Uzbek literature, as his activity is an expression of his multifaceted, unique talent.Jamal Kamal is not only a poet, but also a publicist, translator, and scholarly literary critic. Thanks to the masterful pen of Jamal Kamal, a number of literary masterpieces of the world long ago turned into the spiritual heritage of the Uzbek people.

"He alone was able to carry out such colossal and painstaking work that it would be difficult for several translators to complete together for their whole life - they translated into the Uzbek language about thirty separate works, and poems of more than twenty poets."

\section{ANALYSIS}

The thematic content of the verses of Jamal Kamal is very wide. It is known that the greatness of the creator is not assessed by the number of works created by him, but is determined by his painstaking work and concern for literature, and is also appreciated by fans of his work and popular recognition. The national poet Jamal Kamal has earned high recognition and dignity for his talent, determination, devotion to the lyrics and sincere disposition, nobility, humanity. "Studying literature, I came to the conclusion that all the sciences in the world relate to one side of life, and literature to the other. All sciences serve the human body, and literature serves the human soul and gives energy, strength to the human spirit. The spirit determines your humanity, humanity, "said the poet [3, p.17]. In fact, in the poetic world of Jamal Kamal, the subject of the soul, the heart of a person dominates. In the following eight-poem, the poet refers to obscene vices of human behavior:

The content of the eight-octave roughly sounds like this:

Posing forever as the heroes of animals

Fables are themselves weaving a man. 


\section{Literary Motives of Sufizm and Spiritual, Moral Ideas in the Lyrics of Jamal Kamal}

Ever blaming others for misconduct

He presents himself with a dove of innocence.

Selfishness, betrayal, intrigue and enmity -

You will read and understand that human vice

There can be so much hostility in animals

All this is yours, better admit your vice.

The material wealth of a person does not determine his level of humanity; he attains perfection only if there are moral, ethical, moral qualities. Our great ancestor Alisher Navai called the man "The Crown of the Universe." Of all beings, Allah created man by a sweet creature, revered by all.

A man, no matter how hard he tries to cover his inner world with his beautiful appearance, still in one day his present will become apparent. Just as a person needs a mirror in order to admire his appearance, he also needs a mirror of the soul, which introduces him to his own inner world, his character, in order to be able to correct his spiritual world, following any pattern. The same motive in one of the contents of the poem by Jamal Kamal is unanimously repeated:

The man called the beauty of the universe

He alone comes to the world.

Opening up a speck of dust in a destined moment,

Despondency and pain after burns hearts.

The man called the beauty of the universe

Live brave and brave, and nothing more.

And only then open a speck of dust

And only then burn hearts with despondency.

In fact, a person is evaluated by the moral qualities of a person. The heights of humanity are achieved only by spirituality. A person is worthy of such a title only if he has high humane qualities.

Man needs humanity

For a flower is odorless,

there is brushwood, firewood.

Not every outwardly similar to a person can be called a person. If in him there are no spiritual and moral qualities of a person, then he is equal to a creature, an animal. If the flower is odorless, then what purpose is it to be a flower, it is just a wood-plant.

"Hey Man, the governor of Allah on Earth, beloved servant of God, a noble family! Be worthy of this calling! Be tall in looks, do not be a slave to your longings! Do not forget that your last marina is the abode of Allah, "says the poet. In the work of Jamal Kamal, the ideas of self-awareness and self-search are always relevant:

I looked for him, searched desperately,

With the desire to reach it to the bottom

Suffocated so much and in the end

My truth was revealed before me

I looked at him, dizzy.

Hopelessness again blocked my path.

Which side

I don't look, my eyes are watery,

Wherever I look, my heart contracts [4, p. 56].

\section{DISCUSSION}

If you pay attention to what the lyrical hero is looking for essence, truth - then he is looking for himself. The hero understood that the essence, the truth is weighty, from which side do not look at him, the road is covered with hopelessness, eyes are watery, the soul is filled with grief and despair. Human life is a holy journey that begins with the spiritual life and leads to the path to material life, and back holds the path to the afterlife.

In this material life, he is not born in order to stay forever, but in order to return to his real homeland, to the world of angels. The intermediate road is a test road. The space in the middle is joy and sorrow, labor and torment, truth and falsehood, victories and defeats, happiness and sorrow. And so, the destiny of a person and his life path - matters travel (hijrat), the relocation of his soul. And in the language of Sufism, "hijrat" (travel) means: renunciation of the bad and low character and the sending to the country of high ideals and morals. To understand the essence, we must go through this path of testing in perfection and dignity. In the lyrics of Jamal Kamal, the red line is the idea of understanding the essence of truth, or rather, divine truth. It is true that truth is one, odd, lonely. She is one, since she was created by God. Truth reigns in everything: in heaven and on earth. Only his dominion on earth is different from the heavenly one, because on earth the lie also rules.

Among creatures created by God, only man can distort the truth with a lie, a lie with a truth. "Truth, I am your beloved!' - the poet's lyrical hero is addressing. It is known that the teaching of Sufism calls for the renunciation of obscene character. Therefore, in the world provided to us with the universal values of the Islamic spirit, we praise the highest morals and deny the vices of man. For example, one of such ailments of a human nature is stinginess; in the same poem of Jamal Kamal, the real face of a stingy person is exposed. If in the poem the mirror of the soul of a pure man with a heart is likened to one drop of mercury, "a pure heart is a drop of mercury", and the avaricious heart is depicted "as a suffocating child in a smoky hog." The poet sympathizes with the state of stinginess; he likens such people to shadows, commenting that stinginess is not a human thing - this is the work of the devil, Satan.

There's a piece of bread at the hands of the merchant,

Heavier than death ... meditate.

Knowing is misfortune, know

And misfortune is an understanding of the earth.

I didn't die of hunger, although I didn't live like Harun,

I lived a life with a pinch, then with a flower,

But my happiness is that I was not a miser.

And I lived a life and my heart was pure [4, p.109].

In the poem, given in the form of a poetic figure Talmeh, Harun - a symbol of stinginess. With such a Talmeche, a historical event is recreated in memory and makes harmony with the depicted phenomenon, or the depicted event and lyrical experience acquire scale and breadth. But the lyrical hero is happy with his life, 
although he was not rich like Harun, but he has cleaner than the wealth of the whole world - a big pure heart. The poet Jamal Kamal, who managed to introduce the ideas of Eastern philosophy into his poems, which could infuse the soul and heart of a person, educate and cure him, turn his heartfelt gaze into the True Path and raise it to Hakka (i.e., to approach Allah).

In the works of Jamal Kamal, inspiration from the poetic heritage of the Oriental classics Imam Gazzali, Omar Khayyam, Fariduddin Attar is clearly traced. The poet experienced especially vivid impressions during his trips to Iran, which were reflected in the collection of poems "Travel Notebook". Poems written under the influence of the ruby of Omar Khayyam are saturated with the ideas of Sufism:

Oh my god, for you I am your slave, living soil

One day is not small, on the second day I'm more,

Don't blow the wind so hard, don't shake it so much

In a motley tree, I'm just a green leaf ...

In Sufism literature, a commonly used theme is the theme of "land-soil." In the symbolism of oriental literature, the idea of modesty of human nature is embodied in the meaning of the word soil. The basis for this is to look for from the holy Quran, where Odam Ato (Adam) was created from clay soil, since the soil was more modest from all the substances that the Lord turned to when creating man. Ahmad Yassawi, a prominent representative and founder of the Turkic branch of Sufi literature, said: "Be the soil, let peace come upon you", putting great importance in these lines, while the very definition of a person is impossible without spiritual stress, without asceticism, without sincere dedication up to willingness to sacrifice life.

\section{CONCLUSION}

In literature, the tasavwuf Sufi is a person who is likened to the soil. The generosity of the soil is limitless, but arrogance is not in its element. Only in the works of Jamal Kamal can one find the use of the word "soil" in combination with the definition of "living" - "Living soil".

The first line of the poet's poem states that a person must live, aware of his helplessness before God, be humble and humble, then the second line hints that in this world where everyone passes the trials of fate, life does not go along a smooth road, without anxiety and excitement, without misfortune and failure. In the third line, the poet refers to the image of the "wind". In the literature of Sufism, the wind represents the four elements, and symbolically means haste.

In the text of the poem, with the help of the poetic antithesis of the images of "soil" and "wind", a sharp contrast is achieved, and the poet alludes with subtlety through the image of the "green leaf", which sways from the wind, as it were, easily shakes the person's longing desires leading to misconduct. "Anvoy ooch" - a motley tree - is a symbol of the coffin. In the poem, this symbolic concept instills fleetingness, the passing meaning of life. In this short-lived life, he is urged not to follow the path of the wind of passions and desires, but is invited to be humble like soil.

\section{REFERENCES}

1. Ochilov E. Translation skills of Jamal Kamal. Uzbek language and literature. T..., 2009., 26 pp.

2. Khakkulov. Tasavwuf and lyrics. T .: Literature and Art, 1991

3. Jamal Kamal. Favorites. Farewell to the eyelid. Fan., 2007.

4. Jamal Kamal. Travel Notebook. T.: Tamaddun. 2012.

5. Akhmedova Mehrinigor, Baqoyeva Muhabbat. Analysis of "Spirituality" Category and its Structure in the English Language. International Journal of Innovative Technology and Exploring Engineering (IJITEE) ISSN: 2278-3075, Volume-8, Issue-9S3, July 2019

6. Kholikova Nozima Nematilloyevna, Saidov Khayrulla Shavkatovich.Observation and Analysis of the Peculiarities of English and Uzbek Detective Genre (in the Examples of J.H.Chase's Works International Journal of Innovative Technology and Exploring Engineering (IJITEE) ISSN: 2278-3075, Volume-8, Issue-9S3, July 2019 